\title{
Extending existing recommended military casualty evacuation timelines will likely increase morbidity and mortality: a UK consensus statement
}

\author{
Nicholas James Scallan @ (1, ${ }^{1,2}$ D D Keene, ${ }^{1}$ J Breeze, ${ }^{3}$ T J Hodgetts, ${ }^{4}$ P F Mahoney ${ }^{1}$
}

\begin{abstract}
- Additional material is published online only. To view please visit the journal online (http://dx.doi.org/10.1136/ bmjmilitary-2020-001517).

${ }^{1}$ Academic Department of Military Anaesthesia and Critical Care, Royal Centre for Defence Medicine, Birmingham, UK ${ }^{2}$ Currently Serving: 3 Medical Regiment, Army Medical Services, Preston, UK ${ }^{3}$ Department of Maxillofacial Surgery, Royal Centre for Defence Medicine, Birmingham, UK

${ }^{4}$ Senior health Advisor \& Head of Army Medical Services, Army Headquarters, Andover, UK
\end{abstract}

\section{Correspondence to}

Lt Col D D Keene, Academic Department of Anaesthesia and Critical care, Royal Centre for Defence Medicine, Birmingham B15 2WB, UK; damian.keene@ uhb.nhs.uk

Received 6 May 2020 Accepted 12 May 2020

Published Online First 14 July 2020

\begin{abstract}
Introduction Future conflicts may have limited use of aviation-based prehospital emergency care for evacuation. This will increase the likelihood of extended evacuation timelines and an extended hold at a forward hospital care facility following the completion of damage control surgery or acute medical interventions.

Methods A three-round Delphi Study was undertaken using a panel comprising 44 experts from the UK armed forces including clinicians, logisticians, medical planners and commanders. The panel was asked to consider the effect of an extended hold at Deployed Hospital Care (Forward) from the current 2-hour timeline to $+4,+8$, +12 and +24 hours on a broad range of clinical and logistical issues. Where $75 \%$ of respondents had the same opinion, consensus was accepted. Areas where consensus could not be achieved were used to identify future research priorities.
\end{abstract}

Results Consensus was reached that increasing timelines would increase the personnel, logistics and equipment support required to provide clinical care. There is a tipping point with a prolonged hold over 8 hours, after which the greatest number of clinical concerns emerge. Additional specialties of surgeons other than general and orthopaedic surgeons will likely be required with holds over 24 hours, and robust telemedicine would not negate this requirement.

Conclusions Retaining acute medical emergencies at 4 hours, and head injuries was considered a particular risk. This could potentially be mitigated by an increased forward capacity of some elements of medical care and availability of a CT scanner and intracranial pressure monitoring at over 12 hours. Any efforts to mitigate the effects of prolonged timelines will come at the expense of an increased logistical burden and a reduction in mobility. Ultimately the true effect of prolonged timelines can only be answered by close audit and analysis of clinical outcomes during future operations with an extended hold.

\section{INTRODUCTION}

Casualty evacuation timelines for UK service personnel who are injured or suffer from acute medical conditions are broadly based on descriptions within a NATO document termed Allied Joint Publication (AJP) 4-10. ${ }^{1}$ The first version (edition A) was published in 2006 and formally introduced increasingly accepted concepts such as damage control surgery (DCS). ${ }^{2}$ It stated that battlefield advanced trauma (BATLS) and battlefield advanced resuscitation techniques should occur within 1 hour of wounding. DCS was recommended within
2 hours and further surgical procedures (at that point termed primary surgery) within 4 hours. This came to be termed the 1-2-4 principal, and has also been called 'clinical timelines' (Figure 1).

An update to initial medical care timelines was published in 2010, describing the need for first aid (bleeding and airway control) within $10 \mathrm{~min}$, skilled medical aid within 1 hour and DCS within 2 hours of wounding. ${ }^{3}$ This became known as the 10-1-2 timeline (Figure 1). The evidence was based on analysis of treatment times and associated mortalities in Afghanistan ${ }^{4}$ and was introduced into UK medical doctrine. ${ }^{5}$

The 2015 update (V.B) to NATO AJP 4-10 formalised the 10-1-2 timeline. ${ }^{6}$ However, the UK used 10.1.2 (2) +2 where (2) refers to the time taken to deliver DCS, and the +2 refers to a 2-hour evacuation to Deployed Hospital Care (Rear) DHC(R) for in-theatre surgery after the end of DCS. ${ }^{6}$ The term 'Primary Surgery' was also dropped in this 2015 update and instead replaced with 'in-theatre surgery'.

The 2019 update (V.C) to AJP 4-10 adopted the 10-1-2 (2)+2 timeline as the NATO recommendation (Figure 1). ${ }^{7}$ Additionally, while recognising that the UK still used the term 'in-theatre surgery', it did not reference it, and instead used the +2 to describe 'further surgical, resuscitative, diagnostic and specialist care capabilities necessary to stabilise the patient for strategic evacuation should be made available within 2 hours of tactical evacuation after DCS ${ }^{7}$

\section{Deployed Medical Capability Study}

The relatively small geographical area comprising the UK military area of operations in the Afghanistan conflict (Op HERRICK), combined with comprehensive air superiority allowed consistently rapid aeromedical evacuation of service personnel from point of injury to a medical treatment facility (MTF). ${ }^{8}$ The 2014 UK Deployed Medical Capability Study (DMCS) concluded that if Op HERRICK had occurred with a less permissive air environment, it would have had a direct impact on aeromedical casualty evacuation. ${ }^{9}$ This would increase the likelihood of prolonged field care and the time to provision of DCS and acute medicine at Deployed Hospital Care (Forward) (DHC(F)). In addition, there would likely be an increase to the subsequent time to delivery of further surgery at DHC(R). ${ }^{10}$

The DMCS 2014 review concluded that 'Extending the timeline from 2 hours to 4 hours (for 
A

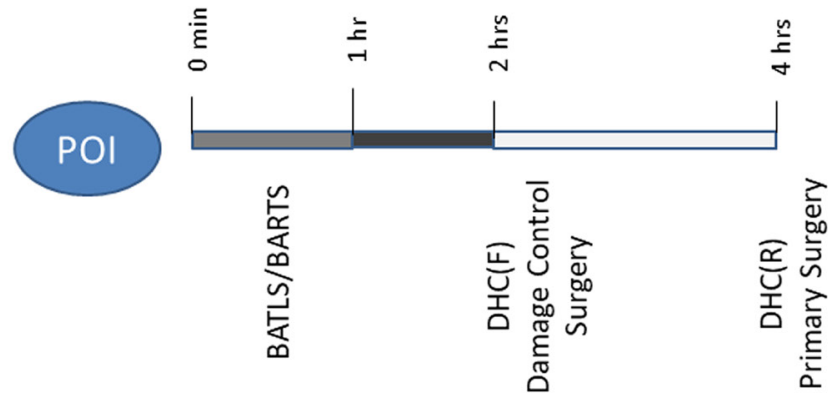

B
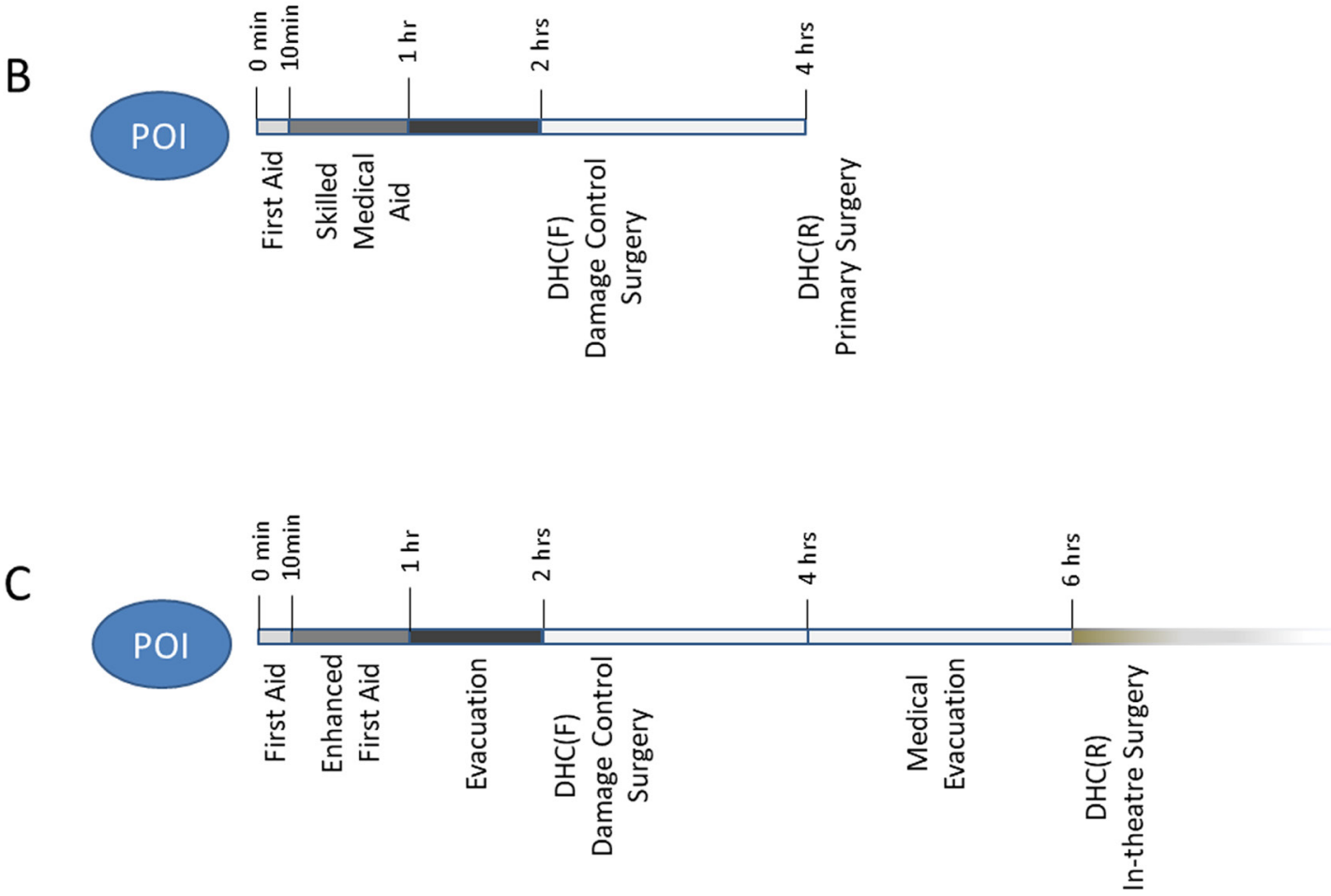

Figure 1 Progression of evacuation timelines from the beginning of Op HERRICK to the present day. (A) The 1-2-4 principle used by the UK military in 2006. (B) The 10-1-2 principle used by the UK military in 2010. (C) The 10-1-2 (2)+2 principle as described in the current Allied Joint Publication (AJP) 4-10 NATO timelines document (adapted from NATO [7]). DHC(F), Deployed Hospital Care (Forward); DHC(R), Deployed Hospital Care (Rear); POI, point of injury.

DCS and acute medical care), can probably be achieved without detriment to survival rates. In most scenarios this could facilitate Primary Surgery (PS) out of the country of intervention, but within a Regional Hub or Allied facility'. It additionally states that 'The UK should advocate, within NATO, the principle of extending the Medical Planning Guidelines between DCS and primary surgery from +2 hours to +4 hours.'

Despite these recommendations it was noted that there is a paucity of research looking at the effect of prolonged timelines on casualty outcome. There was no consensus within the Defence Medical Services (DMS) on whether increasing the time between DHC(F) and DHC(R) would impact on casualty outcome. The aim of this study was to identify areas of consensus in order to guide future planning and research. ${ }^{11} 12$

\section{METHOD}

Panel selection

A Delphi-type study was undertaken ${ }^{13}$ with a panel of experts and a questionnaire-based assessment to investigate a complex or imprecise issue with the aim of reaching consensus. A Delphi approach was used because no robust evidence currently exists to answer this question. ${ }^{14}$ The panel was drawn from academic departments within the DMS, defence consultant advisors, military clinical directors and medical planners. This paper is based on the internal report but has involved a reanalysis of key results. ${ }^{13}$

\section{Question asked}

The panel was asked to predict the potential effects of extending the time between completion of DCS at DHC(F) and arrival to 


\begin{tabular}{|c|c|c|c|c|c|c|}
\hline Disagree & & & Neutral & Agree & & \\
\hline $\begin{array}{l}\text { Strongly } \\
\text { disagree }\end{array}$ & & & & & $\begin{array}{l}\text { Strongly } \\
\text { agree }\end{array}$ & $\begin{array}{l}\text { Insufficient } \\
\text { knowledge }\end{array}$ \\
\hline 1 & 2 & 3 & 4 & 5 & 7 & NA \\
\hline
\end{tabular}

$\mathrm{DHC}(\mathrm{R})$ from the current +2 hours to $+4,+8,+12$ or +24 hours. In addition, panel members were encouraged to develop further questions as described below. This paper is derived from the original study ${ }^{13}$ and summarises the main findings.

\section{Study structure}

An online Delphi engine was used to deliver the study and comprised the following three rounds:

Round 1. Participants were free to articulate opinions about the proposed timeline extensions. The replies were broadly classified into clinical, logistics, personnel and equipment. The comments from these replies were used by the research team to construct the Delphi Questionnaire for Round 2.

Round 2. Polarised statements were constructed from the results of Round 1 and participants invited to agree or disagree using a 7 -point Likert-type scale, ${ }^{15}$ as shown in Table 1 below.

If over $75 \%$ of responses to a statement were allocated to either disagree (1-3) or agree (5-7), consensus (negative or positive) was achieved. 'Insufficient Knowledge' returns were removed from calculations. The choice of a $75 \%$ consensus point was chosen as existing evidence for a level to reach consensus ranges from $70 \%$ to $80 \% .{ }^{16}$ The majority of statements were subdivided into four stems, relating to the impact of an incremental increase in evacuation timelines $(+4,+8,+12$ and +24 hours). Table 2 shows a sample question. A full list of questions asked alongside the results is available in online supplementary appendix 1.

Round 3. This consisted of all the questions from Round 2 that failed to reach consensus. The questions were represented showing the respondents their previous Round 2 score and the group average. Other participants' anonymous comments were also visible to the respondents.

\section{Results}

Fifty-nine individuals were approached, of whom 44 agreed to participate (Figure 2). Thirty of $44(68 \%)$ participants completed all three rounds of questions. A further 8 (19\%) failed to complete Round 1 but subsequently completed Round 2. Twelve (27\%) participants failed to complete Round 3. The reasons for non-participation included deployment, change in role or a perception the study was outside of an individual's area of expertise. Of the 84 questions, 75 (84\%) reached consensus on at least one time point. A breakdown of panel members by role at time of study is listed in Table 3.

Full results are available in online supplementary appendix 1 . Themes from the main subject areas are summarised below.

Table 2 Example questions from the Delphi Study

\begin{tabular}{lll}
\hline Question & Statement & $\begin{array}{l}\text { (Strongly disagree } \\
\leftarrow \text { strongly agree) }\end{array}$ \\
\hline $\begin{array}{ll}\text { 1. Advanced medical care } \\
\text { closer to the point of }\end{array}$ & i) +4 hours & $1234567 \mathrm{NA}$ \\
wounding is required to +8 hours & iii) +12 hours & $1234567 \mathrm{NA}$ \\
$\begin{array}{l}\text { deliver an increased hold } \\
\text { capability of... }\end{array}$ & iv) +24hours & $1234567 \mathrm{NA}$ \\
\hline
\end{tabular}

\section{Effects of prolonged hold}

Respondents disagreed that a prolonged hold at $\mathrm{DHC}(\mathrm{F})$ would have no effect on worsening morbidity and mortality $(81 \%$ at +8 hours, $94 \%$ at +12 hours and $97 \%$ at +24 hours).

\section{Intensive care unit (ICU) capability}

There was no consensus as to whether increased ICU capability to support a prolonged hold would allow mortality and functional outcome to remain unchanged at any time point. While this question regarding ICU capability was open to interpretation, the panel specifically felt that ICU care would be affected at set time increases by: the emerging sequelae of blast lung (85\%), increased ICU capacity (82\%) and the need for specialist ICU beds $(80 \%)$ at +8 hours; increased ventilator $(75 \%)$ and cardiovascular monitoring (76\%) requirements at +12 hours; and ICU specialists at +24 hours.

\section{Head injury diagnosis and monitoring}

Of the respondents, $81 \%$ agreed CT scanning for head injury would be required if the hold time was increased to +12 hours and $84 \%$ at +24 hours. There was no consensus at +4 hours or +8 hours. Seventy-eight per cent agreed there would be a requirement for intracerebral pressure monitoring with any extension of timeline beyond +2 hours.

\section{Blood products for damage control resuscitation}

Consensus was reached that platelets would be required at all timelines $(79 \%$ agreed at +4 hours, $80 \%$ at 8 hours, $94 \%$ at +12 hours and $100 \%$ at +24 hours). Eighty-two per cent agreed whole blood would be a suitable alternative to component therapy. Seventy-eight per cent disagreed that if there were ongoing transfusion requirements DCS and ICU care could still be delivered with a limited supply of blood products.

Eighty-five per cent of respondents disagreed that effective DCR could be delivered without fresh frozen plasma, or an equivalent, regardless of the timeline. This was not the case for cryoprecipitate or fibrinogen where no consensus was reached. Eighty-six per cent agreed full coagulation monitoring was required at +8 hours, $93 \%$ at +12 hours and $97 \%+24$ hours.

\section{Delayed DCS and in-theatre surgery}

Eighty-three per cent of respondents agreed that at +4 hours temporary vascular shunts would remain adequate, falling to $75 \%$ at +8 hours. No consensus was reached past this point.

Eighty-three per cent agreed that at +4 hours DCS temporising procedures, for example, stapling bowel, would not require revision prior to in-theatre surgery at $\mathrm{DHC}(\mathrm{R})$. There was no consensus past this time point.

Seventy-six per cent agreed improved junction haemorrhage control would be necessary at +12 hours. Exploratory operations to avoid underdiagnosis would be needed from +8 hours $(75 \%)$ and the need for second look surgery reached consensus by +12 hours $(78 \%$ agreed at +12 hours, $81 \%$ agreed at +24 hours). Sixty-three per cent of respondents felt forward siting of limited CT capability would not reduce surgical interventions nor the number of surgical teams required.

Seventy-five per cent agreed that additional specialties of surgeon other than general and orthopaedic surgeons would be required at +24 hours. Eighty-five per cent agreed robust telemedicine would not negate this requirement. Seventy-six per cent agreed increased predeployment surgical training would be necessary, but no consensus was reached on the adequacy of NHS job plans at maintaining the surgical skills required for deployment. 


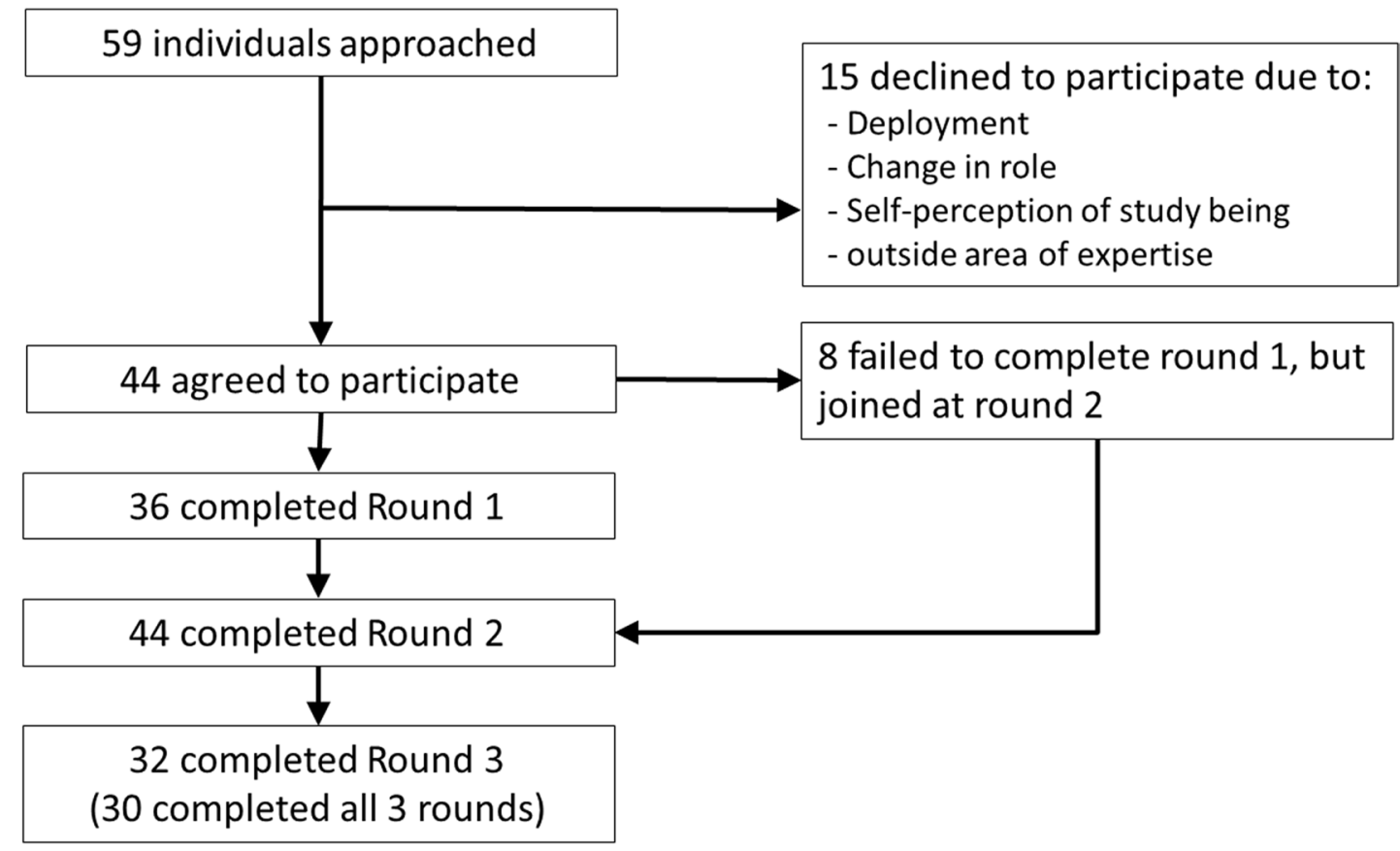

Figure 2 Participation flow chart.

\section{Logistics}

The panel agreed that the outcomes achieved on Op HERRICK could not be delivered within the DHC(F) equipment and real estate footprint $(81 \%$ at +12 hours and $89 \%$ at +24 hours) at the time of the study.

Eighty-one per cent agreed that Medical and Dental Servicing Section support would be needed to manage the increase in power and electromedical equipment demands required for prolonged timelines. Eighty-five per cent agreed current generator technology would not be adequate for prolonged holds nor would current fridge/freezer technology (90\% agreement).

Seventy-seven per cent agreed the operating theatre would require environmental control for increases of +4 hours. There would be a requirement for ward beds over stretchers from +24 hours $(79 \%)$ and from +8 hours in ICU (80\%).

Seventy-six per cent agreed additional equipment could not be placed in the current footprint. Eighty-six per cent agreed that a robust rapid supply chain would not mitigate the impact of remoteness of $\mathrm{DHC}(\mathrm{F})$ facilities nor would it negate the need for extra consumables (79\% agreement). Eighty-nine per cent agreed that flexibility of $\mathrm{DHC}(\mathrm{F})$ would be affected by prolonged holds as patients could not be moved easily (Table 4).

\section{DISCUSSION}

Continual improvements in mortality throughout recent conflicts have raised expectations for survival after military trauma. ${ }^{17-19}$ Reproducing the survival rate achieved at the UK DHC(F) MTF

Table 3 Breakdown of panel by role

\begin{tabular}{lc}
\hline Role at the time of Delphi Study & Number \\
\hline Deputy Assistant Chief of Staff or Acting Head & 8 \\
Defence Professor & 5 \\
Defence Consultant Advisor or Service Consultant Advisor & 17 \\
Medical Staff Officer & 13 \\
Heads of Branch & 7 \\
Clinical Director & 9 \\
\hline
\end{tabular}

at Camp Bastion on Op HERRICK at the start of any future operation will be challenging. There will be no guarantee of air evacuation or fixed MTFs in the country of operation. Even during the winding down phase of Op HERRICK in 2014, a return to greater reliance on land-based evacuation was seen for less severely injured casualties. ${ }^{20}$ Current doctrine recognises these aeromedical evacuation requirements, aptly observing that it 'is the mode of patient transportation with the most limitations and restrictions and the highest safety, support and infrastructure requirements'?

The literature demonstrates continuous improvements in mortality during operations and suggests possible explanations for this but cannot prove causality. Research on the benefit of individual changes was limited to retrospective studies. ${ }^{21-23}$ With time larger prospective studies are bridging this gap. ${ }^{24} 25$ The components of these multiple transformational system changes up to DHC are listed in Table 5.

This Delphi Study considered the effects of increased evacuation timelines and delayed treatment on patient survival and ways of mitigation. Below we discuss the key effects of delayed care at specific time points.

\section{Prolonged hold of +4 hours}

The panel concluded that any increase in timelines would have a negative impact on survival and recovery for acute medical patients. The panel did not highlight how to mitigate these effects. Successive studies have both demonstrated the need for, and honed the process of, resuscitation with blood products. ${ }^{2627}$ The importance of timely evacuation and blood transfusion was demonstrated by reduced mortality of US casualties in the Iraq and Afghanistan conflicts. ${ }^{28}$ This 2019 study showed a perceived need for transfusion support in any prolonged evacuation and noted this came with a logistical cost. It was felt that a robust resupply chain would not negate the need for significant blood stocks to be held at medical facilities. Platelets with their 5-day shelf-life and unique storage requirements provide a particular problem. No consensus was reached regarding fibrinogen and cryoprecipitate. There is now accumulating evidence 
Table 4 Key themes from consensus

\begin{tabular}{clc}
+4 hours & +8 hours & +12 hours \\
\hline & Prolonged hold at Role 2 would impact on morbidity and functional recovery & +24 hours \\
& & Increased formulary required
\end{tabular}

Anaesthetics and ICU

ICP monitoring required for head injuries

Increased emerging sequelae of blast lung

Regional anaesthesia required

Impact of prolonged hold on nursing the patient

Uplift in ventilator capability and cardiovascular monitoring required

ICU specialists required and mortality increases

Surgery

Head injury mortality and morbidity increases

DCS temporising procedures now failing

Exploratory surgery required

Functional recovery from head injury worsens

Temporary vascular shunts failing

Requirement for further 'second look' surgical procedures

Subspecialty surgeons required

Possibility of surgery denied due to

perceptions of futility

Radiology

CT head capability required

Whole body CT scanning required

Labs and transfusion

Blood products (including fibrinogen and platelets)

Full coagulation monitoring required

Full sepsis evaluation required

Biomedical scientists required

Acute medicine

Acute medical emergencies will have increasingly worse outcomes

Thrombolysis required

Evacuation

Consultant physician required

Increase in mortality and morbidity requiring uplift in tactical evacuation clinical

competencies.

DCS, damage control surgery; ICU, intensive care unit.

which supports the use of fibrinogen and French lyophilised plasma, ${ }^{29}$ the latter of which can be stored at room temperature for 2 years. ${ }^{30}$ By comparison, thawed plasma has been shown to reduce mortality in a large-scale RCT, but has a short shelf-life. ${ }^{24}$

Whole blood, either as an emergency donor panel or cold whole blood, may be a suitable alternative. Although the former requires prior planning and may not provide a sustainable solution if the casualty load is high, it has been used to good effect in small teams providing medical support to indigenous forces. ${ }^{29} 3132$ Decisions on evacuation timelines are not linked solely to medical issues; body armour for UK forces in Iraq that provided greater anatomical coverage was introduced based on evacuation timelines of no greater than 2 hours to a Role 2 or 3 surgical facility, whereas previously body armour was designed to protect against injuries for the 20 min evacuation timeline in northern Ireland. ${ }^{33}$

\section{Prolonged hold of +8 hours}

The panel concluded that head injury outcome would worsen with any increase beyond +8 hours. Given that head injury is historically a high cause of morbidity and mortality this is a significant area of concern. ${ }^{34}$ In order to minimise the effect on head injury outcome it was felt full CT scanning capabilities would be necessary by 12 hours. ICP monitoring was suggested as a way to mitigate the impact of prolonged timelines on head injury survival although international opinion is split on its effect on mortality and morbidity in traumatic brain injury. ${ }^{35}$ Furthermore, the subsequent evacuation chain may alter sensor positioning, cause patient movement or the sensor to be dislodged, all of which affect the accuracy of ICP monitoring . ${ }^{36}$

Our study participants recommended full coagulation monitoring for timelines of +8 hours. Given that the global impairment of haemostasis found in acute traumatic coagulopathy is evident within the first hour, it is now recognised that correctly diagnosing TIC early and targeted delivery of blood components (guided by laboratory results) is best practice. This is also true for the subsequent trauma-induced coagulopathy. ${ }^{37} 38$

During DCS patients may receive temporising procedures to allow onward evacuation. The panel felt temporising procedures in general would require further surgery at timelines of +8 hours. However, vascular shunts specifically were felt likely to remain adequate for up to 8 hours, after which time there was no consensus as to their viability. This is in keeping with documented cases of wounded US service personnel..$^{39}$ Increasing 


\begin{tabular}{|c|c|}
\hline Topic & Component \\
\hline \multirow[t]{2}{*}{ Predeployment training } & Predeployment simulation ${ }^{49}$ \\
\hline & MOST course ${ }^{42}$ \\
\hline \multirow[t]{4}{*}{ Prehospital care } & $\begin{array}{l}<\mathrm{C}>\mathrm{ABC} \text { paradigm }{ }^{50} \\
\text { Tourniquets }^{51}\end{array}$ \\
\hline & $\begin{array}{l}\text { Quikclot haemostatic agent }{ }^{52} \\
\text { HemCon }^{53} \\
\text { Celox }^{53}\end{array}$ \\
\hline & Pelvic binders ${ }^{54}$ \\
\hline & Consultant-led MERT ${ }^{55}$ \\
\hline \multirow[t]{6}{*}{ Damage control resuscitation ${ }^{56}$} & Permissive hypotension ${ }^{5758}$ \\
\hline & Ratio of transfusion of blood components ${ }^{2627}$ \\
\hline & $\mathrm{TXA}^{59}$ \\
\hline & Damage control surgery ${ }^{42}$ \\
\hline & Consultant-led resuscitation ${ }^{19}$ \\
\hline & Whole blood ${ }^{60}$ \\
\hline \multirow[t]{3}{*}{ Diagnostics } & ROTEM $^{61}$ \\
\hline & FAST $^{62}$ \\
\hline & $\mathrm{CT}^{62}$ \\
\hline \multirow[t]{2}{*}{ Iterative improvements } & Major trauma audit for clinical effectiveness ${ }^{17}$ \\
\hline & Key performance indicators ${ }^{63}$ \\
\hline
\end{tabular}

$<C>A B C$, Catastrophic Haemorrhage, Airway, Breathing, Circulation; FAST, Focused Abdominal Ultrasound in Trauma; MERT, Medical Emergency Response Team; MOST, Miltary Operational Surgical Training; ROTEM, Rotational Thromboelsatometry; TXA, Tranexamic acid.

timelines may result in some of these temporising measures failing during evacuation.

\section{Prolonged hold of +12 hours}

From 12-hour holds onwards the panel felt there would be a stepwise need for additional equipment and personnel with facilities requiring improved environmental control, cold chain and generator capability. All this would, in turn, make the facilities less manoeuvrable.

Further to this the panel felt that a CT scanner would be required to help assess for occult bleeding at +12 hours (and undiagnosed injuries at +24 hours). This is in contrast to civilian practice where hyperacute CT imaging is an integral part of trauma management. ${ }^{40}$ The lack of early CT is reflected by a predicted increase in exploratory surgery to rule out undiagnosed injuries at 8 hours. Deploying CT scanning comes with a significant logistical and mobility burden to any medical facility.

\section{Prolonged hold of +24 hours}

The panel agreed that there is a need for either subspecialist surgeons or the provision of additional skill sets to core surgeons; this is a view supported in the literature. ${ }^{1041}$ No consensus was reached on whether NHS job plans would maintain the required skills for deployment. This view that extra training would be required for NHS-based surgeons was identified early during the conflict in Afghanistan and was mitigated by the development of predeployment high fidelity simulation, overseas attachments and military-specific surgical courses. ${ }^{18} 42-44$ It is also worth noting that additional training for combat medical technicians to enable them to hold onto casualties for extended periods before $\mathrm{DHC}(\mathrm{F})$ is also being addressed,. ${ }^{45}$ At the time of the study respondents felt telemedicine alone could not mitigate this. However, this is an emerging and rapidly evolving technology which may have an impact in the future. ${ }^{47}$ The coverage of the OSPREY personal armour front and rear plates used in the current VIRTUS personal armour system are based on the premise of DCS within 2 hours. ${ }^{33}$ Any increase in medical timelines may require a reassessment of personal armour coverage.

\section{Limitations}

This Delphi Study presents consensus opinion, rather than objective evidence. This is in part mitigated through discussion of findings in the context of corroborating or conflicting material from the literature.

Rapidly emerging technological advances may make things possible now which were not considered feasible at the time of conducting the study in 2015. The extension of timelines was considered in the context of the current Op HERRICK framework of that time; future operating environments will give rise to new clinical, logistic and organisational challenges and these 'unknown unknowns' will need to be addressed.

The panel selection has been described, but this was not an open forum for contributions across the DMS and did not include senior non-commissioned officers. Panel members in clinical roles were all practising doctors, as opposed to clinicians filling staff officer roles. Therefore, problems which could be envisioned by a more multidisciplinary consideration may not have been captured in this study.

Round 3 reviewed the questions which did not reach consensus and allowed respondents to adjust their answers with the anonymised comments and group average. While this allowed for respondents to gain a different view it may well have introduced bias into answers. The effects of increased hold time and therefore increased patient numbers were not fully explored. Approaches to triage will have to be adjusted based on availability of resources. ${ }^{48}$

\section{CONCLUSIONS}

Consensus was reached that there will be an increase in morbidity and mortality, with any increased hold at $\mathrm{DHC}(\mathrm{F})$ beyond 8 hours. Treating acute medical emergencies at 4 hours was considered a particular risk, and mitigation may be achieved by forward placing additional elements of care. Any efforts to mitigate the effects of prolonged timelines will come at the expense of an increased logistical burden and a reduction in mobility. Ultimately the true effect of prolonged timelines can only be answered by close audit and analysis of clinical outcomes during future operations with an extended hold.

Acknowledgements The authors thank Lieutenant General (Rtd) Professor Martin Bricknell for his advice on the preparation of this manuscript. The authors also thank Lt Col Hume and Col T Wooley for compiling the internal report on behalf of the Academic Department of Military Anaesthesia and Critical Care, Royal Centre for Defence Medicine, Birmingham, UK. The authors also thank Professor MackwayJones, University of Manchester, for providing academic assistance and direction with running the Delphi Study engine.

Contributors NS, DK and JB wrote the manuscript with guidance from PM and TH.

Funding The authors have not declared a specific grant for this research from any funding agency in the public, commercial or not-for-profit sectors.

Competing interests None declared.

Patient consent for publication Not required.

Ethics approval Not applicable

Provenance and peer review Not commissioned; internally peer reviewed.

ORCID iD

Nicholas James Scallan http://orcid.org/0000-0001-8314-5827 


\section{REFERENCES}

1 Lane I, Stockinger Z, Sauer $\mathrm{S}$, et al. The Afghan Theater: a review of military medical doctrine from 2008 to 2014. Mil Med 2017;182:32-40.

2 NATO Standardisation Office. Allied Joint Medical Support Doctrine 4-10 (Version A). North Atl Treaty Organ, 2006. Available: https://shape.nato.int/resources/site6362/ medica-secure/publications/ajp-4.10(a).pdf

3 Supreme Headquarters Allied Powers Europe. Allied command operations directive for medical support to operations (AD) 83-1 edition 2. North Atl Treaty Organ 2010

4 Tai NRM, Brooks A, Midwinter M, et al. Optimal clinical timelines--a consensus from the academic department of military surgery and trauma. J R Army Med Corps 2009;155:253-6.

5 Ministry of Defence. Joint doctrine publication 4-03, 3rd edition. Jt Med Doctine 2011.

6 Nato Standardisation Office; Ministry of Defence. Allied joint doctrine for medical support 4-10, edition B version 1, with UK national elements. North Atl Treaty Organ 2015

7 Nato Standardisation Office. Allied joint doctrine for medical support 4-10, edition C version 1. North Atl Treaty Organ 2019;3-7:3-8.

8 Bricknell MC, Johnson A. Forward medical evacuation. J R Army Med Corps 2011;157:S444-8.

9 Ministry of Defence. Deployed medical capability study. D/VCDS/1/5/1 2014.

10 Bricknell M. For debate: the operational patient care pathway. J R Army Med Corps 2014;160:64-9.

11 Bricknell M, Finn A, Palmer J. For debate: health service support planning for largescale defensive land operations (Part 2). J R Army Med Corps 2019;165:176-9.

12 Bricknell M, Finn A, Palmer J. For debate: health service support planning for largescale defensive land operations (Part 1). J R Army Med Corps 2019;165:173-5.

13 Hume D, Woolley T, Hodgetts TJ, et al. Timelines Delphi study. Army Med Dir - Intern Rep 2015.

14 Linstone H, Turoff M. The delphi method. Boston: Addison Wesley Publishing, 1975. Available: https://www.researchgate.net/file.PostFileLoader.html?id=563b341d5cd9 e375988b45bc\&assetKey=AS\%3A292381292285964\%401446720541026

15 Likert R. A technique for the measurement of attitudes. Arch Psychol 1932.

16 Ulschak FL. Human resource development: the theory and practice of need assessment. Reston Pub. Co 1983

17 Penn-Barwell JG, Roberts SAG, Midwinter MJ, et al. Improved survival in UK combat casualties from Iraq and Afghanistan: 2003-2012. J Trauma Acute Care Surg 2015;78:1-20.

18 Vassallo D. A short history of CAMP Bastion Hospital: preparing for war, National recognition and Bastion's legacy. J R Army Med Corps 2015;161:355-60.

19 Vassallo D. A short history of CAMP Bastion Hospital: part 2-Bastion's catalytic role in advancing combat casualty care. J R Army Med Corps 2015;161:160-6.

20 Dickinson A, Dalal S, Beales L. Returning to contingency: the forward trauma team. J $R$ Army Med Corps 2016;162:400-5.

21 O'Reilly D, König T, Tai N. Field trauma care in the 21st century. J R Army Med Corps 2008; 154:257-64.

22 Rehn M, Weaver A, Brohi $\mathrm{K}$, et al. Effect of prehospital red blood cell transfusion on mortality and time of death in civilian trauma patients. Shock 2019;51:284-8.

23 Naumann DN, Hancox JM, Raitt J, et al. What fluids are given during air ambulance treatment of patients with trauma in the UK, and what might this mean for the future? results from the rescuer observational cohort study. BMJ Open 2018:8:e019627.

24 Sperry JL, Guyette FX, Brown JB, et al. Prehospital plasma during air medical transport in trauma patients at risk for hemorrhagic shock. N Engl J Med 2018;379:315-26.

25 Chapman MP, Moore EE, Chin TL, et al. Combat: initial experience with a randomized clinical trial of plasma-based resuscitation in the field for traumatic hemorrhagic shock. Shock 2015;44 Suppl 1:63-70.

26 Borgman MA, Spinella PC, Perkins JG, et al. The ratio of blood products transfused affects mortality in patients receiving massive transfusions at a combat support Hospital. J Trauma 2007:63:805-13.

27 Holcomb JB, Tilley BC, Baraniuk S, et al. Transfusion of plasma, platelets, and red blood cells in a 1:1:1 vs a 1:1:2 ratio and mortality in patients with severe trauma. JAMA 2015;313:471-82

28 Howard JT, Kotwal RS, Stern CA, et al. Use of combat casualty care data to assess the US military trauma system during the Afghanistan and Iraq conflicts, 2001-2017. JAMA Surg 2019;154:600.

29 Daniel Y, Habas S, Malan L, et al. Tactical damage control resuscitation in austere military environments. J R Army Med Corps 2016:162:419-27.

30 Sailliol A, Martinaud C, Cap AP, et al. The evolving role of lyophilized plasma in remote damage control resuscitation in the French armed forces health service. Transfusion 2013:53 Suppl 1:65S-71.

31 Vanderspurt CK, Spinella PC, Cap AP, et al. The use of whole blood in US military operations in Iraq, Syria, and Afghanistan since the introduction of low-titer type 0 whole blood: feasibility, acceptability, challenges. Transfusion 2018;59:trf.15086.

32 Campbell K, Naumann DN, Remick K, et al. Damage control resuscitation and surgery for Indigenous combat casualties: a prospective observational study. BMJ Mil Health 2019:doi: 10.1136/jramc-2019-001228. [Epub ahead of print: 20 June 2019].
33 Breeze J, Lewis EA, Fryer $\mathrm{R}$, et al. Defining the essential anatomical coverage provided by military body armour against high energy projectiles. J R Army Med Corps 2016;162:284-90

34 Keene DD, Penn-Barwell JG, Wood PR, et al. Died of wounds: a mortality review. J $R$ Army Med Corps 2016;162:355-60.

35 Forsyth RJ, Raper J, Todhunter E, et al. Routine intracranial pressure monitoring in acute coma. Cochrane Database Syst Rev;29.

36 Kawoos U, McCarron R, Auker C, et al. Advances in intracranial pressure monitoring and its significance in managing traumatic brain injury. Int J $\mathrm{Mol} \mathrm{SC}$ 2015; 16:28979-97.

37 Davenport RA, Brohi K. Cause of trauma-induced coagulopathy. Curr Opin Anaesthesiol 2016;29:212-9.

38 National Institue for Health and Care Excellence. NG39 Major trauma: assessment and initial management. NICE Guidel, 2016. Available: https://www.nice.org.uk/ Guidance/NG39/evidence

39 Taller J, Kamdar JP, Greene JA, et al. Temporary vascular shunts as initial treatment of proximal extremity vascular injuries during combat operations: the new standard of care at Echelon II facilities? J Trauma 2008;65:595-603.

40 Yeguiayan J-M, Yap A, Freysz M, et al. Impact of whole-body computed tomography on mortality and surgical management of severe blunt trauma. Crit Care 2012;16:R101.

41 Breeze J, Blanch R, Baden J, et al. Skill sets required for the management of military head, face and neck trauma: a multidisciplinary consensus statement. J R Army Med Corps 2018;164:133-8.

42 Midwinter MJ. Damage control surgery in the era of damage control resuscitation. $J R$ Army Med Corps 2009;155:323-6.

43 Tai N, Hill P, Kay A, et al. Forward Trauma Surgery in Afghanistan:Lessons Learnt on the Modern Asymmetric Battlefield. J R Army Med Corps 2008;154:14-18.

44 Bricknell MC, McArthur D. Deployed hospital care. J R Army Med Corps 2011;157:S453-6.

45 Hodgetts TJ, Findlay S. Putting role 1 first: the role 1 capability review. J R Army Med Corps 2012;158:162-70.

46 Smith M, Johnston K, Withnall R. Systematic approach to delivering prolonged field care in a prehospital care environment. BMJ Mil Health 2020:doi: 10.1136/ jramc-2019-001224. [Epub ahead of print: 27 Feb 2020]

47 Eder P, Reime B, Wurmb T, et al. Prehospital telemedical emergency management of severely injured trauma patients. Methods Inf Med 2018;57.

48 Horne ST, Vassallo J. Triage in the defence medical services. J R Army Med Corps 2015;161:90-3.

49 Mercer S, Arul GS, Pugh HEJ. Performance improvement through best practice team management: human factors in complex trauma. J R Army Med Corps 2014;160:105-8

50 Hodgetts TJ, Mahoney PF, Russell MQ, et al. $A B C$ to $\angle C>A B C$ : redefining the military trauma paradigm. Emerg Med J 2006;23:745-6.

51 Kelly JF, Ritenour AE, McLaughlin DF, et al. Injury severity and causes of death from operation Iraqi freedom and operation enduring freedom: 2003-2004 versus 2006. J Trauma 2008;64:S21-7.

52 Boulton AJ, Lewis CT, Naumann DN, et al. Prehospital haemostatic dressings for trauma: a systematic review. Emerg Med J 2018;35:449-57.

53 Winstanley M, Smith JE, Wright C. Catastrophic haemorrhage in military major trauma patients: a retrospective database analysis of haemostatic agents used on the battlefield. J R Army Med Corps 2019;165:405-9.

54 Lee C, Porter K. The prehospital management of pelvic fractures. Emerg Med J 2007; $24: 130-3$.

55 Apodaca A, Olson CM, Bailey J, et al. Performance improvement evaluation of forward aeromedical evacuation platforms in operation enduring freedom. J Trauma Acute Care Surg 2013:75:S157-63.

56 Hodgetts TJ, Mahoney PF, Kirkman E. Damage control resuscitation. J R Army Med Corps 2007:153:299-300.

57 Bickell WH, Wall MJ, Pepe PE, et al. Immediate versus delayed fluid resuscitation for hypotensive patients with penetrating torso injuries. N Engl J Med 1994;331:1105-9.

58 Morrison CA, Carrick MM, Norman MA, et al. Hypotensive resuscitation strategy reduces transfusion requirements and severe postoperative coagulopathy in trauma patients with hemorrhagic shock: preliminary results of a randomized controlled trial. $J$ Trauma 2011;70:652-63.

59 , Shakur H, Roberts I, et al, CRASH-2 trial collaborators. Effects of tranexamic acid on death, vascular occlusive events, and blood transfusion in trauma patients with significant haemorrhage (CRASH-2): a randomised, placebo-controlled trial. Lancet 2010;376:23-32

60 Cap AP, Beckett A, Benov A, et al. Whole blood transfusion. Mil Med 2018;183:44-51.

61 Allcock EC, Woolley T, Doughty H, et al. The clinical outcome of UK military personnel who received a massive transfusion in Afghanistan during 2009. J R Army Med Corps 2011;157:365-9.

62 Gay DAT, Miles RM. Use of imaging in trauma decision-making. J R Army Med Corps 2011;157:S289-92.

63 Marsden ME, Sharrock $A E$, Hansen $C L$, et al. British military surgical key performance indicators: time for an update? J R Army Med Corps 2016;162:373-8. 